\title{
PUBLISITAS DAN PROMOSI FILM ADA APA DENGAN CINTA? 2
}

\author{
Lilis Puspitasari ${ }^{1}$, Jimi Narotama Mahameruaji ${ }^{1}$, Sri Seti Indriani ${ }^{1}$ \\ ${ }^{1}$ Universitas Padjadjaran
}

\begin{abstract}
ABSTRAK
Publisitas bagi sebuah film merupakan suatu alat untuk menyebarkan pesan yang direncanakan dan dilakukan untuk mencapai tujuan pemasaran lewat media tertentu untuk kepentingan dari sebuah production house tanpa pembayaran tertentu pada media. Dalam film orang yang bergerak untuk mempublikasikan film dikenal dengan istilah publisis. Kegiatan publisitas dalam bidang pemasaran direncanakan dalam rangka mendukung tujuan pemasaran suatu produk atau jasa perusahaan. Salah satu area bidang publisitas ini adalah entertainment publicity, dimana salah satu produknya adalah film. Penelitian ini bertujuan untuk menggambarkan publisitas dan promosi sebagai alat komunikasi pemasaran pada film Ada Apa Dengan Cinta 2. Berdasarkan hasil penelitian, terdapat 3 tahapan yang diterapkan dalam mengembangkan strategi publisitas film AADC 2. Tahap Pertama adalah Menentukan tujuan publisitas; Tahap kedua, Mengidentifikasi Target Sasaran; Tahap Ketiga, Mendefinisikan Pesan dari Film; Tahap keempat Menentukan strategi publisitas, dan Tahap Terakhir adalah Monitoring dan evaluasi.
\end{abstract}

Kata-kata Kunci: Film; Publisitas; Promosi.

\section{PUBLICITY AND PROMOTION OF ADA APA DENGAN CINTA 2 MOVIE}

\begin{abstract}
Publicity for a movie is a tool for disseminating messages that are planned and performed to achieve marketing objectives through a particular medium for the benefit of a production house without any payment to the media. In film the person who moves to publicize the film is known as publisis. Publicity activities in the field of marketing are planned in order to support the purpose of marketing a product or service company. One area of publicity is entertainment publicity, where one of its products is a movie. This study aims to describe publicity and promotion as a marketing communication tool in the movie Ada Apa Dengan Cinta 2. Based on the research results, there are 3 stages applied in developing the AADC film publicity strategy 2. The First Phase is Determining the purpose of publicity; Second stage, Identifying Target Goals; Third Stage, Defining Messages from Movies; The fourth stage Determining the publicity strategy, and the Last Stage is Monitoring and Evaluation.
\end{abstract}

Keywords: Movie; Publicity; Promotion.

Korespondensi: Lilis Puspitasari. Universitas Padjadjaran. Jl. Raya Bandung-Sumedang Km. 21 Sumedang. Email: lilis.puspitasari@unpad.ac.id

Submitted: July $1^{\text {st }}, 2016$, Revision: October $1^{\text {st }}, 2016$, Accepted: December $1^{\text {st }}, 2016$

ISSN: 2548-687X (cetak), ISSN: 2549-0087 (online)

http://jurnal.unpad.ac.id/protvf 


\section{PENDAHULUAN}

Publisitas bagi sebuah film merupakan suatu alat untuk menyebarkan pesan yang direncanakan dan dilakukan untuk mencapai tujuan pemasaran lewat media tertentu untuk kepentingan dari sebuah production house tanpa pembayaran tertentu pada media. Dalam film orang yang bergerak untuk mempublikasikan film dikenal dengan istilah publisis. Kegiatan publisitas dalam bidang pemasaran direncanakan dalam rangka mendukung tujuan pemasaran suatu produk atau jasa perusahaan. Salah satu area bidang publisitas ini adalah entertainment publicity, dimana salah satu produknya adalah film.

Peran publisis dalam mempublikasikan film yang telah dihasilkan sangat besar. Namun, dalam perfilman Indonesia hal ini seringkali terabaikan. Padahal film yang dibuat dengan sangat baik dan sarat informasi positif sekalipun menjadi tidak berarti jika tidak dipublikasikan dengan baik. Melakukan kegiatan publisitas sebuah film bukanlah hal yang sederhana dan mudah. Setiap Production House tentu akan berusaha untuk sekreatif dan seinovatif mungkin dalam merancang dan melakukan strategi pemasaran agar dapat menarik minat dari masyarakat penonton. Kegiatan pemasaran yang dilakukan oleh perusahaan tersebut harus dikomunikasikan dengan baik kepada khalayak sasaran agar produk yang ditawarkan dapat diminati oleh masyarakat, disinilah publisis mengambil peran yang sangat penting. Keberadaan peran publisis di sebuah lembaga produksi film merupakan keharusan secara fungsional dan operasional dalam upaya menyebarluaskan atau mempublikasikan sesuatu kegiatan atau aktivitas lembaga yang bersangkutan yang ditujukan baik kepada publik internal maupun publik eksternal.

Ada Apa Dengan Cinta? 2 merupakan film yang penayangannya sangat paling dinantikan oleh penonton Indonesia tahun 2016 karena merupakan sekuel dari film Ada Apa Dengan Cinta? yang release tahun 2002.
Kesuksesan film ini tidak hanya materil tetapi juga menimbulkan tren baru di masyarakat. Hal ini dibuktikan dengan meningkatnya kunjungan wisatawan ke Yogyakarta yang menjadi lokasi latar cerita film, seperti Gereja Ceker Ayam, Sellie Coffe, dan Greenhost Boutique Hotel.AADC?2 berhasil diputar serentak di Indonesia, Malaysia, dan Brunei Darussalam. Selain itu AADC? 2 juga ditayangkan di 5 kota Australia meliputi Melbourne, Sydney, Adelaide, Darwin, dan Brisbane mulai 23 Agustus 2016. Tak hanya itu AADC?2 juga ditayangkan sebagai film pembuka Fukuoka International Film Festival 2016.

Film Ada Apa dengan Cinta? 2 merupakan film Indonesia hasil produksi Miles Productions yang merupakan sekuel dari Ada Apa dengan Cinta?yang rilis tahun 2002. Film ini mulai ditayangkan di Indonesia pada 28 April2016 dan masih dibintangi oleh pemeran film sebelumnya, termasuk Dian Sastrowardoyo sebagai Cinta dan Nicholas Saputra sebagai Rangga. Film ini menjadi film Indonesia terlaris kedua tahun 2016 karena berhasil meraih 3,6 juta penonton. Kesuksesan film ini juga tercatat melampaui pencapaian film pertamanya yang juga yang dirilis 14 tahun sebelumnya.

\section{TINJAUAN PUSTAKA}

Pada dasarnya tugas pokok public relations adalah menciptakan citra positif perusahaan di mata publiknya. Citra positif dapat terbentuk bila publik mempunyai persepsi yang positif terhadap perusahaan. Persepsi ini harus lengkap dan tidak sepotong - sepotong. Agar hal itu dapat dicapai, maka publik harus dalam kondisi kecukupan informasi (wellinformed) tentang perusahaan. Artinya, tidak ada kesenjangan informasi antara perusahaan dengan publiknya dan sebaliknya. Karena itu, public relations dituntut menjaga arus informasi agar berjalan dua arah timbal balik.

Informasi adalah segala hal yang dapat mengurangi ketidakpastian atau keragu raguan akan situasi tertentu. Bila tidak mendapatkan informasi yang cukup gambaran 
tentang perusahaan akan sepotong - potong. Kegiatan menyampaikan atau menyebarkan informasi ini disebut kegiatan publikasi. Publikasi berasal dari kata "Publicare" yang artinya "untuk umum". Jadi publikasi adalah kegiatan mengenalkan perusahaan sehingga umum (publik dan masyarakat) dapat mengenalnya.

Selama ini terdapat tanggapan bahwa publikasi dan publisitas kegiatan yang sama, yaitu kegiatan mengenalkan perusahaan kepada pihak luar. Pendapat ini memang bisa diterima. Namun dalam konteks kegiatan public relations, publisitas dan publikasi berbeda. Perbedaan ini terletak pada media yang digunakan. Publisitas adalah publikasi yang menggunakan media massa sebagai sarana penyebarluasan informasi. Publisitas adalah publikasi perusahaan yang dimuat media massa. Dengan demikian, pengertian publikasi lebih luas dan publisitas adalah bagian dari aktivitas publikasi.

Pengertian publisitas menurut beberapa ahli: Otis Baskin dkk, "a broad term that refers to the publication of news about an organization or person for which time or space was not purchase "mendefinisikan publisitas sebagai : istilah, yang merujuk pada publikasi berita tentang organisasi atau individu dimana untuk itu tidak perlu membayar waktu atau space. Doug Newson dkk, "information about an organization that is carried as editorial - not advertising - content in a publication or news medium" yang mendefinisikan publisitas adalah informasi tentang organisasi yang dikemas sebagai editorial- bukan iklan - pada medium publikasi dan berita.

Berarti dari kacamata media massa, publisitas adalah informasi yang disediakan oleh sumber luar yang digunakan oleh media karena informasi itu memiliki nilai berita. Media tidak menarik harga untuk menempatkan informasi ini dalam halaman surat kabar atau dalam slot waktu radio dan televisi. Karena itu dimuat atau tidak adalah sepenuhnya hak media massa. Sumber penyampai informasi (misalnya
PR perusahaan) tidak dapat mengontrol atau menentukan agar dimuat.

Contoh publisitas antara lain berita di media massa tentang peningkatan kinerja sebuah perusahaan, launching produk baru, berita feature tentang temuan ilmiah terbaru dari sebuah universitas, liputan kegiatan para artis di acara infotainment, tabloid hiburan yang memuat daftar group band yang akan konser, resensi film atau buku, dan sebagainya. Publisitas merupakan dampak diketahuinya informasi oleh publik. Berita - berita di atas mengandung publisitas bagi yang diberitakannya. Well, dengan penjelasan diatas mengenai publikasi dan publisitas mungkin bermanfaat untuk menjawab kebingungan yang melanda.

\section{METODE PENELITIAN}

Metode deskriptif dapat diartikan sebagai prosedur pemecahan masalah yang diselidiki dengan menggambarkan keadaan subjek atau objek dalam penelitian dapat berupa orang, lembaga, masyarakat dan yang lainnya yang pada saat sekarang berdasarkan fakta-fakta yang tampak atau apa adanya.

Tujuan dari penelitian deskriptif adalah untuk membuat deskripsi, gambar-gambar, atau lukisan secara sistematis, faktual dan akurat mengenai fakta-fakta, sifat-sifat serta hubungan antar fenomena yang diselidiki.

Penelitian deskriptif hanya memaparkan situasi dan peristiwa, tidak mencari atau menjelaskan hubungan, tidak menguji hipotesisatau membuat prediksi.Metode deskriptif dirancang untuk mengumpulkan informasi tentang keadaan nyata yang sekarang berlangsung. Tujuan utama dalam menggunakan metode ini adalah untuk menggambarkan sifat suatu keadaan yang sementara berjalan pada saat penelitian dilakukan dan memeriksa sebabsebab dari suatu gejala tertentu.Metode deskriptif juga membantu kita mengetahui bagaimana caranya mencapai tujuan yang diinginkan. 
Jenis penelitian deskriptif ini mempelajari masalah-masalah dalam masyarakat, serta tata cara yang berlaku dalam masyarakat serta situasi-situasi tertentu, termasuk tentang hubungan-hubungan, kegiatan-kegiatan, sikap-sikap, pandanganpandangan, serta proses-proses yang sedang berlangsung dan pengaruh-pengaruh dari suatu fenomena. (Moleong, 2006 : 138)

Penelitian ini bertujuan untuk menggambarkan publisitas dan promosi sebagai alat komunikasi pemasaran pada film Ada Apa Dengan Cinta? 2.

\section{HASIL DAN PEMBAHASAN}

Melanjutkan kembali film dengan rentang waktu cukup lama yang juga menghadirkan para pemain yang sama serta dengan karakter yang juga sama seperti film sebelumnya, bukanlah pekerjaan yang mudah. Tentu saja hal yang membuat film ini dinanti nanti oleh para fans fanatiknya adalah rasa penasaran akanbagaimana kehidupan para tokoh utama film ini setelah 14 tahun. Film AADC 2 masih mengambil tema persahabatan geng Cinta serta kelanjuta jalinan asmaranya dengan tokoh Rangga.

Berdasarkan hasil penelitian, terdapat 3 tahapan yang diterapkan dalam mengembangkan strategi publisitas film AADC? 2. Tahap Pertama adalah Menentukan tujuan publisitas; Tahap kedua, Mengidentifikasi Target Sasaran ; Tahap Ketiga, Mendefinisikan Pesan dari Film; Tahap keempat Menentukan strategi publisitas, dan Tahap Terakhir adalah Monitoring dan evaluasi.

\section{Tahap 1: Menentukan Tujuan Publisitas Film AADC? 2}

Berdasarkan hasil wawancara dengan Ade Kusumaningrum, Koordinator publisis film AADC?2 terdapat 2 tujuan utama dalam perencanaan publisitas film tersebut, yang pertama adalah untuk membangun awareness serta audience interest terhadap film, dan yang kedua adalah membangun media relations untuk mendapatkan exposure media. Seperti yang disampaikan dalam wawancara sebagai berikut:

"AADC 2 sebelum release sudah promosi tujuannya untuk maintenance awareness, bahwa akan ada sequel. Film itu adalah sebuah brand. AADC itu brand nya sudah kuat, sebagai sebuah brand yang sudah besar tentu saja perlu waktu untuk membangun interest audience. Selain itu tujuan kita juga ingin membangun media relations untuk mendapatkan exposure seluas luasnya."

\section{Tahap 2: Menentukan Target Sasaran Film AADC?2}

Penentuan target sasaran merupakan tahapan yang sangat penting dalam mengembangkan publisitas yang efektif. Tahapan ini diperlukan untuk mengembangkan strategi media serta menentukan tools dan teknik yang bisa digunakan dalam perencanaan publisitas.

Penentuan target sasaran dilakukan setelah membaca scenario secara keseluruhan. Menurut Ade, dari skenario itu pula sudah bisa ditetapkan siapa target audience serta profil penonton secara geografis. Target sasaran dari publicity and promotion film AADC?2 dibagi menjadi 2 kelompok, yaitu Kelompok Primary Target yang merupakan penonton AADC1. Kelompok ini berada dalam range usia late twenties, early thirties, dan kelompok Secondary Target, yaitu anak-anak muda. Penentuan kelompok ini berdasarkan berdasarkan hasil survey bahwa penonton bioskop itu ada di kisaran 15-25 tahun.

Menurut Ade, pengelompokan target sasaran merupakan hal yang sangat krusial karena akan sangat menentukan arah komunikasi, bentuk komunikasi serta penentuan media yang akan digunakan. Selain itu penentuan target sasaran juga menentukan key message dalam materi publisitas, tampilan/image para pemain yang akan dikeluarkan, yang tentu saja berpengaruh pada bagaimana wardrobe yang digunakan, serta 
dandanan para pemain juga disesuaikan dengan karakter dan umurnya.

\section{Tahap 3: Mendefinisikan Pesan Film}

Seperti yang sudah disampaikan sebelumnya, film AADC yang menuai sukses di tahun 2002 telah menimbulkan rasa penasaran khalayak akan kelanjutan kisah dari sosok Rangga yang pergi meninggalkan Cinta. Hal tersebut menjadi tantangan bagi Miles Film untuk menyuguhkan Ada Apa Dengan Cinta ? 2 sebaik kualitasnya dengan film pertamanya dulu. Tak dapat dipungkiri, meneruskan film yang sudah lebih dari satu dekade dengan tetap menjaga kualitas dan 'rasa' yang sama, bukanlah hal yang mudah. Kekhasan lain yang dipertahankan dari film sequel ini adalah unsur puisi yang juga menjadi daya tarik tersendiri bagi para penggemarnya.

Materi/isi pesan dibedakan berdasarkan timeline promosi dan publisitas film AADC 2, yang dibagi menjadi 3 periode, yaitu Periode Remembering, Periode The Now, dan Periode What's Next. (1) Periode Remembering : yaitu periode sebelum proses produksi film AADC2. Materinya menyangkut hal-hal yang bisa mengingatkan target audience terhadap film AADC 1, serta menginformasikan bahwa film AADC 2 akan dibuat. (2) Periode The Now : yaitu periode proses shooting AADC 2 telah dimulai. Materi publisitasnya terkait dengan selamatan pada saat memulai proses produksi, Shooting, Cast (pemain), serta Behind the Scene. Untuk menjaga rasa penasaran penonton tidak semua shooting diberitakan, dan beberapa nama pemain masih tetap dirahasiakan. (3) Periode What's Next : Materi publisitas pada periode ini menyangkut gala premiere, serta segala aspek yang ada di film dibedah dan di rilis satu-satu, diantaranya tentang profil seniman jogja yang terlibat di film, tempat

Terkait isi materi dari strategi publisitas,selain dengan produser Mira Lesmana, Ade dan tim juga melakukan diskusi dengan pihak pemain, serta menerapkan the do's and the dont's selama shooting terhadap para pemainnya. Hal ini dilakukan dalam rangka menjaga brand AADC yang sudah kuat tadi. Selain itu juga untuk membangkitkan rasa penasaran audience, materi dari publisitas betulbetul sangat dijaga, karena tidak bisa sembarangan memberi tahu apa yang ada dalam film AADC 2, untuk mencegah adanya spoiler.

\section{Tahap 4: Menentukan Strategi dan Taktik Komunikasi}

Kesuksesan dari film AADC 2 ini juga tidak terlepas dari strategi publisitas yang dilakukan dalam memberikan exposure terhadap film ini. Menurut Ade Kusumaningrum, dalam menangani publisitas dan promosi dari sebuah film pada prinsipnya tidak ada template yang baku dari publisitas sebuah film, namun sangat tergantung dari konten film.

“......berbicara tentang publisitas film itu tidak ada yang sama sesuai dengan film nya/konten film...alias customize. Ketika kita akan menggarap sebuah project film Kita pasti akan menelaah projeknya, film tentang apa, pesan apa yang ingin disampaikan, target audience nya siapa ..baru sampai masalah logistik seperti waktu pengerjaannya dan budget karena akan menentukan scope, besar kecilnya. Tidak ada template dalam merancang publisitas film, template-nya terkait waktu saja.misalnya kapan release, jadi paling template nya ada ini ...tapi kemasan promosi nya beda-beda"

Dalam merancang strategi publisitas pada sebuah film, idealnya menurut Ade sudah dimulai pada saat scenario lock. Tahap Scenario Lock ini merupakan akhir dari tahap film development, yaitu sebelum proses produksi film dimulai, bahkan siapa yang menjadi pemain pun biasanya belum ditentukan pada tahap ini, tetapi sudah menjadi materi publisitas. Namun diakui Ade bahwa proses penggarapan publisitas film yang dimulai pada saat scenario lock tersebut sangat jarang didapatkan. 
" ....kita sangat jarang untuk mendapat hal seperti itu kebanyakan filmnya biasanya udah jadi, jadi terus terang kami sedang menekankan pada banyak fihak bahwa kami mengerjakannya di awal ya....karena kita gak bisa bergerak jadi sesuatu juga jika tidak dibangun sejak lama....promosinya film itu sangat bergantung pada draft yang sudah final."

Strategi publisitas AADC 2 ini bisa dikatakan sebuah strategi yang ideal karena dilakukan sebelum proses produksi dimulai. Ide awal muncul dari hasil membaca scenario film. Selain itu yang juga penting disini adanya keterlibatan produser film, Mira Lesmana, melalui proses diskusi dan brainstorming sampai penentuan strategi publisitas merupakan hasil kesepakatan bersama produser film.

"Untuk film AADC 2, kita ketemu mba Mira memang draft ceritanya sudah final, meskipun bahwa masih akan ada perubahan-perubahan di lapangan ya wajarlah, paling nggak skenario sudah lock, jadi begitu scenario lock kemudian kita ngobrol untuk bisa baca skenarionya. Dari baca skenario dari situ kita ngasih pitching idea strategi publisitasnya seperti apa. Kebetulan kalo AADC 2 konsep yang kita pikirkan dengan mba Mira sudah sama, tinggal brainstorming lagi, sampai kita menentukan strategi publisitasnya seperti apa"

Terkait strategi pemasaran film, dua alat pemasaran penting dan tidak dipisahkan satu sama lain adalah publisitas dan promosi. Hal ini disebabkan karena karakter industri film di Indonesia tidak seperti industri perfilman di luar negeri, contohnya Hollywood. Pada industry film di luar negeri seperti Hollywood, terdiri dari studio, bioskop, dan production house, yang mana masing-masing memiliki peran yang berbeda.PH itu hanya memproduksi film, sementara yang mengurus promosi, distribusi dan penjualanadalah urusan studio.

“.....disini studio gak ada karena disini bioskop cuma sedikit, exhibitor disini cuma ada cinemax, 21 dan cgv blitz, dan platinum baru. Basicly yang paling banyak mayoritas itu 21. Jadi tidak memungkinkan berdirinya adanya studio studio seperti diluar. Disini PH langsung ke exhibitor. PH ngurus segala macem, termasuk juga ngurus promosi selain publisiti, sehingga kita nyebutnya publicity and promotion"

Karena promosi dan publisitas tidak bisa dilepas sebagai satu kesatuan sebagai alat pemasaran film, promosi yang bentuknya lebih ke event menjadi jadi bagian integral dari publisitas. Jadi ketika strategi publisitasnya seperti apa, maka promosinya akan disesuaikan dengam dengan publisitasnya. Artinya strategi publisitas akan terkait dengan bagaimana rancangan promosi eventnya. Berbeda dengan industry film di luar negeri, PH biasanya hanya mengurus bagian publisitasnya saja.

Adapun taktik komunikasi yang digunakan dalam publisitas dan promosi AADC 2 terdiri dari (1) Pre teaser di bioskop; (2) Teaser; (3) Trailer; (4) Aktivasi social media; (5) kerjasama dengan youtuber, instagramer serta blogger; (6) jargon; (7) pembuatan meme; (8) Website; (9) Media luar ruang seperti billboard, (10) original soundtrack; (11) berbagai bentuk media event seperti interview dan talkshow di beberapa tv dan radio yang menjadi media partner; (12) mengeluarkan serangkaian media release; (13) selain itu juga menayangkan TV \& Radio commercial; (14) Outdoor advertising, (15) Promotional event seperti galapremiere di kota Jogja dan acara Nonton bareng di beberapa kota besar; dan (16) Sponsorship.

Untuk membahas strategi publisitas dan promosi yang digunakan dalam film AADC?2, peneliti mengkategorikan berdasarkan media yang digunakan, yang terdiri dari media massa, Media digital/online, media luar ruang dan special events. Media massa yang digunakan mencakup surat kabar, majalah, radio, televisi dan bioskop. Walaupun saat ini promosi film sudah mulai berubah ke social media, penggunaan media massa konvensional masih 
digunakan karena di Indonesia masih punya kecenderungan bahwa keluarga itu masih nonton tv dan baca Koran, walaupun memegang HP. Jadi porsi antara media konvensional dan media digital bisa dikatakan masih fifty-fifty. Adapun media massa yang digunakan terbatas pada media partner, yaitu MRA Group, SCTV, Femina Group, Koran Kompas, dan Kapan Lagi.com.

Taktik yang digunakan adalah : media release, press conference, media talkshow, media interview, yang dilakukan secara periodic dari mulai kick off bahwa akan dibuat film AADC 2, press conference, TV Commercial, TV Concert, Pre Teaser serta Trailer untuk di bioskop, serta Soundtrack untuk radio.

Terkait Interview dengan Media, pihak publisis menerapkan SOP Untuk membatasi melalui media tersebut, pihak publisis menerapkan batasan mana yang bisa dipublish dan mana yang seperti yang disampaikan oleh Ade dalam wawancara berikut ini :

"Untuk TV yang akan melakukan interview kita minta list pertanyaannya, untuk mencegah spoiler, rundown nya seperti apa. Spoiler yang paling penting "Rangga ama Cinta itu jadi gak yah". Pengaturan wawancara serta liputan di media juga disesuaikan dengan karakter pemain. AADC 2 juga tidak menginginkan terlalu banyak gimmick, prinsipnya promosipun tidak sekedar prmosi saja, jadi ketika ada tawaran menjadi bintang tamu di beberapa acara talkshow seperti Hitam Putih dan Ini Talkshow ditolak dengan alasan terlalu banyak gimmick. Jika ada media yang akan melakukan wawancara harus menghubungi dulu manajer, dan dari manajer selalu dilempar lagi kepada pihak publisis. Selama masa promosi semua bentuk interview media diatur dan di screening oleh publisis"

Sementara itu alasan SCTV menjadi satu satunya TV Partner, karena SCTV sudah membeli hak tayang nya jauh sebelum proses produksi. Jadi sudah ada kerjasama iklan walaupun masih membeli lagi slot khusus untuk hari penayangan selama seminggu. Untuk soundtrack kerjasama dengan Aquarius kesepakatan dari awal dengan Aquarius adalah dengan membuat konser AADC 2 dengan SCTV.

Media digital memiliki porsi yang cukup besar. Adapun taktik yang digunakannya adalah aktivasi social media, twitter, facebook, youtube dengan menggunakan akun resmi Miles Production; serta website. Penggunaan social media ini penayangan teaser dan trailer, quiz, membuat meme sebanyak 3 buah dengan Punch Line "Kamu Jahat", dimana meme tersebut dapat memancing orang membuat meme lain yang viral di sosmed.

Selain itu mengundang kerjasama dengan para youtuber, blogger dan intagrammer. Kerjasama dengan para pegiat social media ini dalam pembuatan konten yang mana isinya harus sepersetujuan dari tim publisis. termasuk ketika akan wawancara dengan pemain. Isi wawancara juga harus disesuaikan dengan karakter di film, karena setiap karakter itu punya detail karakter profilnya, memudahkan untuk photo shoot dan wawancara. Untuk AADC cukup banyak informasi yang harus dijaga. Termasuk untuk engagement dengan anak muda sekarang. Jadi sebelum ke bioskop informasi sudah di share di social media youtube, twiteer dan facebook.

"Sosial media pribadi juga digunakan untuk memviralkan, pemain, sutradara, produser, kru semua sangat involve...dalam retweet, regram tetapi pemain tidak boleh posting foto dengan pemain disaat syuting. Social media juga memiliki effect yang besar.Pemain memang tidak harus mempromosikan film, tapi prinsipnya adalah kita promosikan bareng bareng, semua crew, pemain, sampai produser memiliki rasa memiliki yang besar sebagai teamwork." 


\section{Media Promosi dan Iklan}

Yang digunakan adalah :Poster, Standing Paperboard yang dipasang di bioskop bioskop yang menayangkan film AADC2. Serta Billboard yang dipasang di beberapa ruas jalan utama kota kota besaar di Indonesia

Special Events; Special event merupakan salah satu taktik komunikasi yang dirancang oleh organisasi yang tujuan utamanya adalah berinteraksi dengan publik dari organisasi tersebut. Melalui penyelenggaraan special events ini juga diharapkan memperoleh publisitas sebesarnya di media.

Special events dalam rangka mempromosikan film ini adalah Gala Premiere. Berbeda dengan film film sebelumnya yang biasanya dilaksanakan di Jakarta, Gala Premiere AADC?2 dilaksanakan di Yogjakarta tepatnya di Empire XXI pada Sabtu malam, 23 April 2017. Gala Premiere ini dihadiri langsung oleh para pemain, sineas, para seniman dan undangan

Promotional event lain yang diselenggarakan adalah acara nonton bareng yang dilaksanakan di beberapa kota besar.

Partnership/Sponsor; Terkait dengan Sponsorship, AADC 2 memiliki cukup banyak sponsor diantaranya Aqua, L'oreal, Lenovo, Magnum, Line, Telkomsel, Bank BJB. Dengan para sponsor tersebut, pihak publisis juga melakukan koordinasi dalam pembuatan iklan (konsep kreatif iklan), melakukan brainstormingdengan para sponsor jadi untuk menjaga konsistensi karakter.

Untuk film AADC2, bisa dikatakan penentuan target sasaran ini sudah tepat, terbukti banyak penonton SMP dan SMA yang menonton AADC 1 terlebih dahulu melalui channel Youtube atau televisi. Walau tetap penonton yang terbesar adalah sesuai prediksi, AADC 2 yaitu para penonton AADC 1. Dari laporan-laporan serta hasil pengamatan pihak Ade, banyak penonton yang menjadikan acara nonton bareng sebagai ajang reuni.

\section{SIMPULAN}

Berdasarkan hasil penelitian, terdapat 3 tahapan yang diterapkan dalam mengembangkan strategi publisitas film AADC? 2. Tahap Pertama adalah Menentukan tujuan publisitas; Tahap kedua, Mengidentifikasi Target Sasaran ; Tahap Ketiga, Mendefinisikan Pesan dari Film; Tahap keempat Menentukan strategi publisitas, dan Tahap Terakhir adalah Monitoring dan evaluasi.

Adapun taktik komunikasi yang digunakan dalam publisitas dan promosi AADC 2 terdiri dari (1) Pre teaser di bioskop; (2) Teaser; (3) Trailer; (4) Aktivasi social media; (5) kerjasama dengan youtuber, instagramer serta blogger; (6) jargon; (7) pembuatan meme; (8) Website; (9) Media luar ruang seperti billboard, (10) original soundtrack; (11) berbagai bentuk media event seperti interview dan talkshow di beberapa tv dan radio yang menjadi media partner; (12) mengeluarkan serangkaian media release; (13) selain itu juga menayangkan TV \& Radio commercial; (14) Outdoor advertising, (15) Promotional event seperti galapremiere di kota Jogja dan acara Nonton bareng di beberapa kota besar; dan (16) Sponsorship.

\section{DAFTAR PUSTAKA}

Bernstein, Gregory. 2015. Understanding the Business of Entertainment: The Legal and Business Essentials All Filmmakers Should Know. Burlington: Focal Press.

Kerrigan, Finola. 2013. Film Marketing. New York: Routledge.

Lipschultz, Jeremy Harris. 2015. Social Media Communication. New York: Routledge.

Moore, John. 2011. Short Film Distribution: Film Festivals, The Internet, and SelfPromotion. Dulles: Mercury Learning.

Ulin, Jeffrey C. 2014. The Business of Media Distribution: Monetizing Film, TV, and Video Content. Burlington: Focal Press. 